\title{
Urszula Michalak, Sens bycia człowiekiem. W poszukiwaniu ostatecznej perspektywy życia osobowego Archidiecezjalne Wydawnictwo Łódzkie, Łódź 2006, s. 256
}

Człowiek pozostanie na zawsze centrum zainteresowania człowieka, a więc refleksją o sobie samym, choć może często odniesioną do tego drugiego, a nie do siebie samego. Niemniej także człowiek pozostanie najbardziej fascynującym przedmiotem badawczym we wszystkich naukach, bezpośrednio czy pośrednio.

W refleksji wokół człowieka ważne jest traktować go zawsze integralnie, nawet gdy przedmiotem badawczy są tylko wybrane elementy. Niestety, współcześnie dość często nauka zdaje się pochylać nad oderwanymi komponentami człowieka, zapominając jednocześnie o jego całości. Dlatego z uznaniem należy powitać prace s. Urszuli Michalak. Autorka jest członkinią sióstr urszulanek szarych. Wykłada w łódzkiej filii Uniwersytetu Kardynała Stefana Wyszyńskiego oraz w Uniwersytecie Łódzkim. Jest autorką dziewięciu książek poetyckich oraz licznych tekstów naukowych.

Całość książki otwiera spis treści (s. 5-7) oraz przedmowa pióra s. prof. dr hab. Zofii J. Zdybickiej z Katolickiego Uniwersytetu Lubelskiego Jana Pawła II, która zapewne była promotorem tego doktoratu (s. 9). Natomiast po wstępie (s. 11-18) studium podzielone zostało na trzy części, a te z kolei na mniejsze bloki, nawet w systemie trzystopniowym. Poszczególne części poprzedza motto w postaci cytatów z prac św. Tomasza z Akwinu.

Część pierwsza nosi tytuł „Człowiek i świat realny” (s. 19-95). Ukazano najpierw przedfilozoficzne rozumienie rzeczywistości szczególnie osoby ludzkiej (s. 21-51). Ważne jest także przywołanie filozoficznej interpretacji istnienia rzeczywistości (s. 53-81). Wreszcie wskazano na konieczność istnienia Absolutu (s. 83-95).

„Człowiek i jego celowe działanie” to tytuł drugiej części studium s. Urszuli Michalak (s. 97-167). Otwierają ją uwagi o przedfilozoficznej interpretacji celowego działania człowieka (s. 99-124). W konsekwencji ukazano filozoficzne interpretacje celowego działania człowieka (s. 125-167).

Ostatnia część opatrzona została tytułem: „Człowiek w perspektywie Boga” (s. 169-235). Analizę tej problematyki rozpoczynają uwagi o miejscu religii w życiu człowieka (s. 171-189). Wskazano tutaj także na rozumienie religii w nauczaniu św. Tomasza z Akwinu (s. 191-235).

Całość treściową książki zamyka zakończenie (s. 237-241). Od strony formalnej dodano jeszcze bibliografię, która podzielona została na: 1. Źródła; 
2. Literatura cytowana w książce; 3. Literatura przedmiotu (s. 243-256). Trzeba już tutaj zauważyć, że kryterium przyporządkowania nie jest w pełni jasne i jednoznaczne.

Pytania o sens bycia człowiekiem stawiają fundamentalne kwestie odnosząc się do istoty ludzkiej. Święty Tomasz z Akwinu stwierdza wyraźnie: „Człowiek różni się od stworzeń nierozumnych tym, że jest panem swych czynów. Człowiek zaś jest panem swych czynów dzięki rozumowi i woli" (STh I-II, q. 1, a. 1).

Prezentując omawianą książkę s. prof. Zofia J. Zdybicka stwierdza: „Autorka książki «Sens bycia człowiekiem. W poszukiwaniu ostatecznej perspektywy życia osobowego», podejmuje dwa najważniejsze problemy współczesnej kultury: kim jest człowiek oraz czym jest religia i jakie są jej źródła. Jan Paweł II wskazuje na „błąd antropologiczny”, czyli niewłaściwe wizje człowieka jako przyczyny obecnego kryzysu kultury. Z nich wypływają tendencje ateistyczne, sekularyzacyjne, laickie, terrorystyczne (ograniczanie życia ludzkiego do życia na ziemi), skrajny liberalizm, permisywizm, konsumpcyjny styl życia. W tej sytuacji prawda o człowieku i prawda o religii stają się pierwszą potrzebą współczesności” (s. 9). Jest to szczególnie ważna opinia, znacząca u progu dzieła s. Urszuli Michalak.

Przecież „dla współczesnego człowieka wiedza o nim samym stanowi konieczny warunek życia autentycznie ludzkiego, które otwiera na Boga, Źródło i ostateczny cel wszechrzeczy, realizuje się i spełnia także w relacji z innymi ludźmi" (s. 18).

Prezentując książkę uczonej urszulanki warto jeszcze raz przywołać opinię długoletniej siostry Dziekan Wydziału Filozofii KUL: „Lektura książki pomaga zrozumieć zasadniczą prawdę - «nie można zrozumieć człowieka bez Boga». $\mathrm{Na}$ to wskazują filozoficzne (metafizyczne) podstawy religii. Wyjaśnia ona możliwość przyjęcia przez człowieka prawdy Objawionej, prawdy, którą przynosi Chrystus, dzięki której «nie można zrozumieć człowieka bez Chrystusa». Tylko przyjmując taką prawdę o człowieku i religii, można budować kulturę życia i miłości” (s. 9).

Bogata jest bibliografia. Szkoda jednak, że nie sięgnięto do innych prac K. Wojtyły, np. Cztowiek w polu odpowiedzialności (Lublin 1991), Wyktady lubelskie (Lublin 1986) oraz licznych prac Jana Pawła II. W nich można łatwo odnaleźć wiele myśli, które wcześniej formułował jako Metropolita Krakowski, a później znacznie pogłębił i rozwinął.

Ważnym uzupełnieniem i zarazem dopowiedzeniem prowadzonych analiz są stosunkowo liczne cytaty tekstów źródłowych, zwłaszcza z obu Sum Doktora Anielskiego.

Wydaje się, że nakreślone we wstępie zamierzenia autorka osiągnęła, a formułowała je w sposób następujący: „Celem niniejszej książki jest wykazanie, iż człowiek jako osoba, byt świadomy i wolny, jest w stanie poznać prawdę o ist- 
niejącej rzeczywistości i sobie samym oraz w świetle tej prawdy odczytać swoją sytuację bytową. Ta z kolei wskazuje na Absolut - źródło istnienia i ostateczny cel życia ludzkiego, z którym człowiek pozostaje w koniecznej relacji. Uświadomienie sobie owej relacji jest religią. Współczesnemu człowiekowi najbardziej potrzebna jest prawda o nim samym, która $\mathrm{z}$ konieczności domaga się istnienia Boga jako koniecznej przyczyny wszystkiego, co realnie jest. Człowiek dopiero w relacji do Boga odnajduje pełnię swoich możliwości, które może aktualizować zarówno w wymiarze natury, jak i łaski” (s. 18).

Studium s. dr Urszuli Michalak wpisuje się w ciąg refleksji filozoficznej wokół myśli św. Tomasza z Akwinu, ubogaconej wieloma komentarzami, zwłaszcza autorów polskojęzycznych. Wskazany podtytuł dobrze dookreśla zasadniczy temat, co więcej, nadaje mu bardziej twórczy i dynamiczny charakter. W konsekwencji faktycznie dość dobrze wybrzmiewa ostateczna perspektywa życia osobowego człowieka.

Bp Andrzej F. Dziuba 